\title{
Somatotroph recruitment by glucocorticoids involves induction of growth hormone gene expression and secretagogue responsiveness
}

\author{
T E Porter, C E Dean'1, M M Piper', K L Medvedev', S Ghavam \\ and J Sandor \\ Department of Animal and Avian Sciences, University of Maryland, College Park, Maryland 20742, USA \\ ${ }^{1}$ Department of Poultry Science, Texas A\&M University, College Station, Texas 77843, USA \\ (Requests for offprints should be addressed to T E Porter; Email: tp44@umail.umd.edu)
}

\begin{abstract}
Prior research indicates that growth hormone $(\mathrm{GH})$ cell differentiation can be induced prematurely by treatment with glucocorticoids in vitro and in vivo. However, the nature of these responses has not been fully characterized. In this study, the time course of corticosterone induction of GH-secreting cells in cultures of chicken embryonic pituitary cells, responsiveness of differentiated somatotrophs to GH secretagogues, localization of somatotroph precursor cells within the pituitary gland, and the effect of corticosterone on $\mathrm{GH}$ gene expression were determined to better define the involvement of glucocorticoids in somatotroph recruitment during development. Anterior pituitary cells from embryonic day 12 chicken embryos were cultured in $10^{-9} \mathrm{M}$ corticosterone for 4 to $48 \mathrm{~h}$ and were then subjected to reverse haemolytic plaque assays (RHPAs) for GH. Corticosterone treatment for as short as $16 \mathrm{~h}$ increased the percentage of $\mathrm{GH}$ cells compared with the control. When corticosterone was removed after $48 \mathrm{~h}$ and cells were cultured for an additional 3 days in medium alone, the percentage of $\mathrm{GH}$ secretors decreased but remained greater than the proportion of somatotrophs among cells that were never treated with corticosterone. To determine if prematurely differentiated somatotrophs were responsive to $\mathrm{GH}$ secretagogues, cells were exposed to corticosterone for $48 \mathrm{~h}$ and then subjected to $\mathrm{GH}$ RHPAs in the presence or absence of GH-releasing hormone $(\mathrm{GHRH})$ or thyrotropin-releasing hormone (TRH). Approximately half of the somatotrophs induced

to differentiate with corticosterone subsequently released more GH in response to GHRH and TRH than in their absence. The somatotroph precursor cells were localized within the anterior pituitary by culturing cells from the caudal lobe and cephalic lobe of the anterior pituitary separately. Corticosterone induction of $\mathrm{GH}$ cells was substantially greater in cultures derived from the caudal lobe of the anterior pituitary, where somatotroph differentiation normally occurs. GH gene expression was evaluated by ribonuclease protection assay and by in situ hybridization. Corticosterone increased $\mathrm{GH}$ mRNA in cultured cells by greater than fourfold. Moreover, corticosterone-induced somatotroph differentiation involved GH gene expression in cells not expressing GH mRNA previously, and the extent of somatotroph differentiation was augmented by treatment with GHRH in combination with corticosterone. We conclude that corticosterone increases the number of $\mathrm{GH}$-secreting cells within $16 \mathrm{~h}$, increases $\mathrm{GH}$ gene expression in cells formerly not expressing this gene, confers somatotroph sensitivity to GHRH and TRH, and induces $\mathrm{GH}$ production in a precursor population found primarily in the caudal lobe of the anterior pituitary, a site consistent with $\mathrm{GH}$ localization in adults. These findings support the hypothesis that glucocorticoids function to induce the final stages in the differentiation of fully functional somatotrophs from cells previously committed to this lineage.

Journal of Endocrinology (2001) 169, 499-509
\end{abstract}

\section{Introduction}

Differentiation of somatotrophs during embryonic development requires both intracellular and extracellular signals. The pituitary-specific transcription factor Pit- 1 is thought to be responsible for the specification of growth hormone $(\mathrm{GH})$ progenitor cells in the fetal pituitary gland (Ingraham et al. 1988, Li et al. 1990, Castrillo et al. 1991, Lin et al. 1992). In the rat, GH expression is first detected in the fetal pituitary gland on day 15 of gestation
(Nemeskeri et al. 1988, Rodriguez-Garcia et al. 1995) but remains at an extremely low level until day 19, when pituitary messenger RNA (mRNA), GH content and the number of somatotrophs increase sharply (Rieutort 1974, Frawley et al. 1985, Nogami et al. 1989, Rodriguez-Garcia et al. 1995). This steep increase in GH expression has been proposed to be induced by the elevation of endogenous glucocorticoid levels. Administration of dexamethasone to pregnant rats induces early GH expression in day 17 or day 18 fetuses (Nogami \& Tachibana 1993, Nogami et al. 
1995), and glucocorticoids have been shown to effectively stimulate somatotroph differentiation in pituitary cultures derived from rats (Hemming et al. 1984, 1988, Nogami \& Tachibana 1993) and chickens (Morpurgo et al. 1997, Dean \& Porter 1999).

Our laboratory uses chick embryos as a model to study the regulation of somatotroph differentiation. Somatotrophs first appear in the developing chick by embryonic day (e) 14 and become a significant population by e16 (Jozsa et al. 1979, Barabanov 1991, Porter et al. 1995a). This ontogenic profile correlates with the capacity of serum from chick embryos to induce GH cell differentiation in vitro (Porter et al. 1995b), wherein serum from e16 but not e12 can induce the appearance of GH-secreting cells in culture. The GH cell-differentiating activity of e16 chicken serum was attributed to endogenous levels of the adrenal glucocorticoid corticosterone (Morpurgo et al. 1997). Concomitant treatment with corticosterone and GH-releasing hormone (GHRH) was shown to amplify the somatotrophdifferentiating activity of corticosterone in vitro (Dean \& Porter 1999), although this effect required more than 3 days of exposure to the hormones. A single in ovo injection of e16 chicken serum or corticosterone on e11 was also shown to induce somatotroph differentiation in the chick embryonic pituitary in vivo (Dean et al. 1999), and this in vivo response was restricted to embryos administered corticosterone on e11 or e12 and involved increased expression of GH mRNA in the caudal anterior pituitary (Bossis \& Porter 2000), the location of somatotrophs in adult animals.

Although much has been learned regarding the ability of glucocorticoids to induce GH cells from their precursor population, many questions remain, including: (1) what is the time course for glucocorticoid-induced somatotroph differentiation? (2) Is the presence of glucocorticoid necessary to maintain the somatotroph phenotype? (3) Are glucocorticoid-induced somatotrophs responsive to stimulatory hypothalamic secretagogues? (4) Do corticosteroneinduced somatotrophs arise in the caudal anterior pituitary, where GH cells normally reside? (5) Does corticosteroneinduced somatotroph differentiation in vitro involve increased GH gene expression, and if so, (6) is GH mRNA expressed in cells that formerly did not express this gene? The present series of experiments was designed to address these questions using a serum-free culture system and a combination of reverse haemolytic plaque assays for secreted $\mathrm{GH}$, immunocytochemistry for intracellular $\mathrm{GH}$, ribonuclease protection assays for total $\mathrm{GH}$ mRNA and in situ hybridization for GH mRNA expressing cells.

\section{Materials and Methods}

Animals and cell culture

Unless stated otherwise, all cell culture reagents were obtained from Life Technologies (Gaithersburg, MD, USA), and hormones and other chemicals were purchased from Sigma Chemical Co. (St Louis, MO, USA). All media were supplemented with $0 \cdot 1 \%$ BSA, $100 \mathrm{U} / \mathrm{ml}$ penicillin $\mathrm{G}$ and $100 \mu \mathrm{g} / \mathrm{ml}$ streptomycin sulphate. Animals used in this study were Single Comb White Leghorn chicken embryos. All procedures with chicken embryos were approved by the Institutional Animal Care and Use Committee. Fertile eggs were placed in a humidified incubator at $37.5{ }^{\circ} \mathrm{C}$. The normal duration of embryonic development for chickens is 21 days. Embryos were removed on e12, and their anterior pituitary glands were isolated with the aid of a dissecting microscope. The pituitaries were dissociated into individual cells by trypsin digestion and mechanical agitation as described previously (Porter et al. 1995a). e12 pituitary cells were cultured in serum-free medium consisting of a 1:1 mixture of phenol red-free M199 and Ham's F-12 nutrient mixture supplemented with $0 \cdot 1 \%$ BSA, $5 \mu \mathrm{g} / \mathrm{ml}$ human transferrin, $5 \mu \mathrm{g} / \mathrm{ml}$ bovine insulin, $100 \mathrm{U} / \mathrm{ml}$ penicillin $\mathrm{G}$, and $100 \mu \mathrm{g} / \mathrm{ml}$ streptomycin sulphate. Cells were plated in either 12-well tissue culture plates or $60-\mathrm{mm}$ culture dishes coated with poly-L-lysine and allowed to attach for $45 \mathrm{~min}$. Serum-free medium containing the appropriate treatments was then added to a final volume of $2 \mathrm{ml}$. To determine the time course of corticosterone-induced somatotroph differentiation, anterior pituitary cells $\left(2 \times 10^{5}\right.$ cells/well) were cultured in 12-well plates for 4, 8, 16, 24, 36 and $48 \mathrm{~h}\left(37.5{ }^{\circ} \mathrm{C}\right.$; $95 \%$ air-5\% $\left.\mathrm{CO}_{2}\right)$ in medium alone or medium containing $10^{-9} \mathrm{M}$ corticosterone. This concentration of corticosterone was chosen because it was shown to be maximally effective at inducing somatotrophs in our previous work (Morpurgo et al. 1997). After each incubation interval, proportions of cells that released $\mathrm{GH}$ were determined by reverse haemolytic plaque assay (RHPA) as described below. Cells cultured similarly for $48 \mathrm{~h}$ were evaluated subsequently for their ability to release $\mathrm{GH}$ in response to $10^{-8} \mathrm{M}$ synthetic human $\mathrm{GHRH}_{1-40}\left(\mathrm{hGHRH}_{1-40}\right.$; Sigma, G8770) and $10^{-8} \mathrm{M}$ thyrotropin-releasing hormone (TRH) for $2,4,8$, and $20 \mathrm{~h}$ by RHPA. To determine whether continuous exposure to corticosterone was necessary to maintain increased proportions of $\mathrm{GH}$-secreting cells during extended culture, pituitary cells $\left(5 \times 10^{5} /\right.$ well $)$ were first cultured for $48 \mathrm{~h}$ in either medium alone or medium containing $10^{-9} \mathrm{M}$ corticosterone. Then, medium was aspirated from the wells, and the cells were recovered and rinsed thoroughly with Spinner's minimum essential medium (SMEM) and Dulbecco's modified Eagle's medium (DMEM). Subsamples of cells from each treatment were subjected to RHPAs to confirm that corticosterone had induced GH cell differentiation. The remaining cells were cultured for an additional 3 days in either serum-free culture medium alone, medium containing corticosterone $\left(10^{-9} \mathrm{M}\right)$ or hGHRH $_{1-40}\left(10^{-7} \mathrm{M}\right)$ alone, or medium containing both corticosterone and hGHRH$H_{1-40}$. These cells were then recovered and subjected to GH RHPAs. To determine whether corticosterone-induced somatotrophs originated 
in the caudal lobe of the chick anterior pituitary, the microanatomical location of somatotrophs in adult chickens (Lopez et al. 1995), the caudal half and cephalic half of e12 pituitary glands were dissociated separately along with entire anterior pituitary glands from other embryos, and the resulting cells from the caudal lobe, the cephalic lobe and the entire anterior pituitary gland were treated for $24 \mathrm{~h}$ with $10^{-9} \mathrm{M}$ corticosterone. GHcontaining cells were identified by immunocytochemistry as described below. To determine the effect of corticosterone on GH mRNA levels, anterior pituitary cells $\left(3-5 \times 10^{6} /\right.$ treatment) were cultured in $60-\mathrm{mm}$ dishes containing medium alone or medium plus $10^{-7} \mathrm{M}$ corticosterone for $48 \mathrm{~h}$. Subsets of these cells were then subjected to GH RHPA to confirm that corticosterone had induced somatotroph differentiation. Total RNA was isolated from the remaining cells by the acid-guanidine-phenolchloroform extraction method (Chomczynski \& Sacchi 1987) and analysed by ribonuclease protection assay as described below. To further investigate whether somatotroph differentiation involves induction of $\mathrm{GH}$ gene expression, anterior pituitary cells were cultured in medium alone or medium containing $10^{-9} \mathrm{M}$ corticosterone, $10^{-7} \mathrm{M}$ $\mathrm{hGHRH}_{1-40}$, or corticosterone in combination with $\mathrm{hGHRH}_{1-40}$ for 3 days. After culture, the cells were harvested and subjected to in situ hybridization as described below.

\section{Reverse haemolytic plaque assay (RHPA)}

The RHPA procedure allows for detection of hormone secretion from individual cells (Neill \& Frawley 1983). The assays were performed according to the protocol described in detail previously (Smith et al. 1986), using rabbit antiserum against chicken $\mathrm{GH}$ and modifications described earlier (Porter et al. 1995a). Briefly, recovered anterior pituitary cells $\left(1 \times 10^{5} / \mathrm{ml}\right)$ were mixed with an equal volume of an $18 \%$ suspension of protein A-coated ovine erythrocytes and infused by capillary action into previously constructed Cunningham chambers. After cells were allowed to attach for $45 \mathrm{~min}\left(37 \cdot 5^{\circ} \mathrm{C}, 95 \%\right.$ air-5\% $\mathrm{CO}_{2}$ ), chambers were rinsed with DMEM to remove unattached cells. Then, DMEM containing GH antiserum (1:40) and hGHRH $\mathrm{H}_{1-40}\left(10^{-7} \mathrm{M}\right)$ was added to the resulting monolayers of cells. Replicate chambers were incubated for $2,4,8$ or $20 \mathrm{~h}$ as described in the figure legends ( 3 chambers per treatment per time point). Plaque formation was subsequently induced by a 45-min incubation with guinea pig complement (1:40, in DMEM). The cells were then fixed with $2 \%$ glutaraldehyde in $0.9 \%$ saline and stained with methyl green. Chambers were analysed using a light microscope to determine the proportion of GH-secreting cells (plaque formers).

\section{Immunocytochemistry (ICC)}

Cultured cells were rinsed once with PBS and fixed in the culture plates with $3 \cdot 7 \%$ formaldehyde in PBS for $10 \mathrm{~min}$.
The cells were then rinsed with PBS, quenched for 10 min with $2 \% \mathrm{H}_{2} \mathrm{O}_{2}$, blocked for 30 min with $1 \%$ normal goat serum (NGS), and incubated overnight with rabbit anti-chicken GH (1:8000 in PBS). The cells were then processed using rabbit $\mathrm{ABC}$ kits according to the directions supplied by the manufacturer (Vector Laboratories, Burlingame, CA, USA). VIP reagent (Vector Laboratories) was used as substrate for the peroxidase. GH-containing cells were then visualized on an inverted light microscope, and the results expressed as a percentage of all pituitary cells present.

\section{Ribonuclease protection assay (RPA)}

After spectrophotometric determination of RNA recovery from dissociated cells, the quality and quantity of the RNA preparations were verified by subjecting each sample to formaldehyde-agarose gel electrophoresis. Ethidium bromide staining was used to assess RNA degradation and verify content in each sample. Samples used were those for which no evidence of RNA degradation was apparent. Total cellular RNA was then subjected to the GH RPA. The construct used for riboprobe synthesis was produced in this laboratory. A chicken GH (cGH) cDNA (Lamb et al. 1988) was provided by Dr Doug Foster, University of Minnesota. This plasmid was digested with EcoRI and $\mathrm{XbaI}$, and the resulting $\mathrm{cGH}$ cDNA fragment was ligated into the EcoRI and XbaI sites of the pGEM-4Z plasmid vector (Promega, Madison, WI, USA). The resulting plasmid (cGH-AS) was digested with EcoRI, and a 320-base ${ }^{32}$ P-labelled cGH antisense riboprobe synthesized with T7 RNA polymerase and the MAXIscript labelling kit (Ambion, Austin, TX, USA). The RPA was performed using the RPA II kit (Ambion) according to the procedure provided by the supplier. Total cellular RNA (3 to $15 \mu \mathrm{g}$ ) and ${ }^{32} \mathrm{P}$-labelled cGH riboprobe (100 000 c.p.m.) were heated $\left(3-4 \mathrm{~min}\right.$ at $\left.95^{\circ} \mathrm{C}\right)$ and allowed to hybridize overnight at $45^{\circ} \mathrm{C}$. The samples were then treated for $30 \mathrm{~min}$ at $37^{\circ} \mathrm{C}$ with $200 \mu \mathrm{l}$ ribonuclease (RNase) digestion buffer containing $10 \mathrm{U}$ RNase A and 200 U RNase T1. The protected RNA and probe were collected by ethanol precipitation, denatured ( $95{ }^{\circ} \mathrm{C}$ for $3-4 \mathrm{~min}$ ), and separated by electrophoresis through $8 \mathrm{M}$ urea-5\% polyacrylamide gels. Protected bands within the gel were visualized by autoradiography, and relative levels of $\mathrm{GH}$ mRNA were determined by video densitometry coupled with image analysis software (ITTI, St Petersburg, FL, USA). The relative levels of GH mRNA were adjusted for micrograms of RNA analysed in 4 separate trials of this experiment.

\section{In situ hybridization (ISH)}

Cells cultured as described above were attached to polyL-lysine-coated slides (6 slides/treatment; $2 \times 10^{4}$ cells/ slide), fixed in $4 \%$ (wt/vol) paraformaldehyde in $0.01 \mathrm{M}$ PBS for $20 \mathrm{~min}$ at room temperature and overnight at 
$4{ }^{\circ} \mathrm{C}$, UV cross-linked, and washed 3 times in Trisbuffered saline and then once in $2 \times$ saline sodium citrate $(2 \times$ SSC $)$. The slides were then dehydrated sequentially in $50 \%, 70 \%, 90 \%$, and $100 \%$ ethanol containing $0 \cdot 3 \mathrm{M}$ ammonium acetate. ${ }^{35}$ S-labelled antisense cGH riboprobe was synthesized as described above for the RPA, substituting ${ }^{35} \mathrm{~S}-\mathrm{CTP}$ for ${ }^{32} \mathrm{P}-\mathrm{CTP}$. A negative control sense probe, complementary to the antisense probe, was synthesized with SP6 polymerase and BamHI-digested plasmid. The cells on each slide were hybridized with $1 \times 10^{6}$ c.p.m. probe in $100 \mu \mathrm{l}$ hybridization buffer $(50 \%$ formamide, $4 \times$ SSPE (salt sodium phosphate EDTA), $5 \times$ Denhardt's solution, $50 \mu \mathrm{g} / \mathrm{ml}$ yeast tRNA, $50 \mathrm{mM}$ dithiothreitol (DTT) and $5 \mathrm{mM}$ vanadyl ribonucleoside complex) overnight at $45^{\circ} \mathrm{C}$. After incubation, slides were washed in $2 \times$ SSC at room temperature and then treated with RNase A $(20 \mu \mathrm{g} / \mathrm{ml})$ for $15 \mathrm{~min}$ at room temperature. Slides were then rinsed five times in $1 \times \mathrm{SSC}-2 \mathrm{mM}$ DTT and twice in $0.2 \times \mathrm{SSC}-2 \mathrm{mM}$ DTT at $54{ }^{\circ} \mathrm{C}$. Finally, slides were rinsed in water and dehydrated with $50 \%, 70 \%, 90 \%$, and $100 \%$ ethanol. Once dry, slides were dipped in photographic emulsion (Kodak NTB2), exposed for 5 weeks at $4{ }^{\circ} \mathrm{C}$, and then developed.

\section{Statistical analysis}

The data reported are the least squares means \pm s.E. from at least three completely separate experiments with the number of replicates provided in the legend to each figure or in the Results section. For the RHPA, ICC and ISH data, a single percentage of GH-positive cells was determined for each combination of treatments from the replicates for that combination (for a total of at least 300 pituitary cells analysed for each combination in each replicate trial). All data were analysed using the General Linear Models procedure of the Statistical Analysis System (SAS Institute, Cary, NC, USA). Duncan's multiple range test was used for comparisons among treatments. Differences were considered significant at $P<0 \cdot 05$.

\section{Results}

Time course of somatotroph induction

Exposure to corticosterone for as few as $16 \mathrm{~h}$ significantly $(P<0 \cdot 01 ; n=3)$ increased the percentage of $\mathrm{GH}$-secreting cells in cultures of e12 pituitaries from $1 \cdot 8 \pm 0 \cdot 3 \%$ to $4 \cdot 8 \pm 0 \cdot 3 \%$ of all cells (Fig. 1). Proportions of somatotrophs were also increased following exposure to corticosterone for 24,36 , and $48 \mathrm{~h}$. At $48 \mathrm{~h}$, the percentage of $\mathrm{GH}-$ secreting cells following exposure to corticosterone $(8 \cdot 8 \pm 0 \cdot 5 \%)$ was further increased $(P<0 \cdot 01)$ relative to levels at 16, 24 and $36 \mathrm{~h}$.

\section{Effect of corticosterone withdrawal on proportions of somatotrophs}

To determine if continued exposure to corticosterone was necessary to maintain somatotrophs, cells were treated

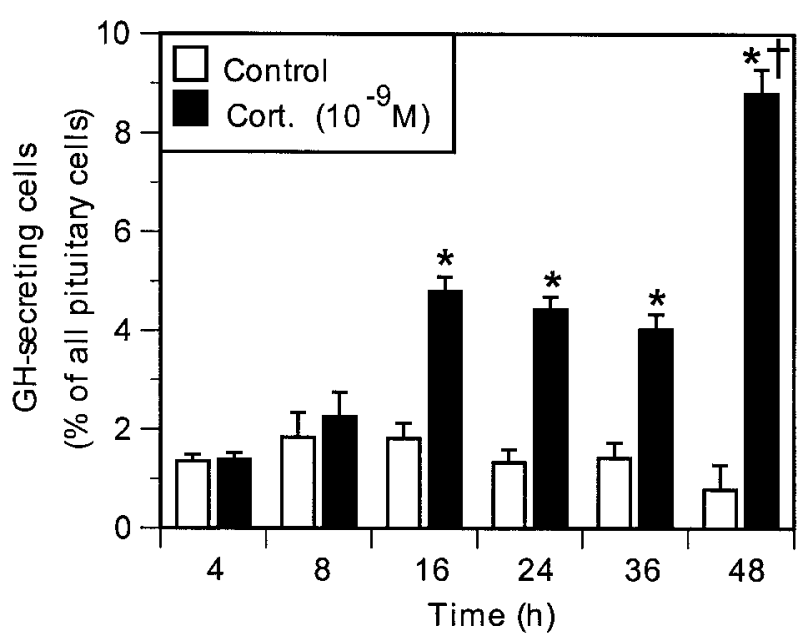

Figure 1 Time course for corticosterone induction of $\mathrm{GH}$-secreting cells. E12 pituitary cells were exposed to medium alone or medium containing corticosterone (Cort.; $1 \times 10^{-9} \mathrm{M}$ ) for 4 to $48 \mathrm{~h}$ in culture. After these culture periods, the cells were recovered and subjected to RHPAs for $\mathrm{GH}$ in which the cells were incubated with antiserum $(1: 40)$ and GHRH $\left(1 \times 10^{-7} \mathrm{M}\right)$ for $8 \mathrm{~h}$. Results are expressed as percentages of total pituitary cells that secreted GH in the RHPA. The data are the least squares means \pm S.E. from three independent experiments. Values denoted with an asterisk are significantly different $(P<0 \cdot 01)$ from the control value for that time point. The value denoted with a dagger at $48 \mathrm{~h}$ is significantly increased $(P<0 \cdot 01)$ relative to all other values. Identical results were obtained with plaque assays performed for $20 \mathrm{~h}$ (data not shown).

with corticosterone for $48 \mathrm{~h}$ followed by an additional $72 \mathrm{~h}$ with corticosterone, GHRH or no hormonal supplement. Treatment with corticosterone for $48 \mathrm{~h}$ increased the proportion of $\mathrm{GH}$ secretors to $4 \cdot 2 \pm 0 \cdot 4 \%$ of all pituitary cells compared with $0 \cdot 5 \pm 0 \cdot 1 \%$ of cells cultured in medium alone (Fig. 2; $P<0 \cdot 05 ; n=4)$. When corticosterone was removed, the percentage of somatotrophs dropped significantly to $2 \cdot 5 \pm 0 \cdot 4 \%$ of all cells. However, this was still a significantly greater proportion than detected among cells that were never exposed to corticosterone during this experiment $(0 \cdot 9 \pm 0 \cdot 2 \%)$. GHRH was not more effective than medium alone for maintaining the proportion of somatotrophs during the final 3 days of culture. Continuous exposure to corticosterone further increased the proportion of somatotrophs during the final 3 days of culture to $5 \cdot 4 \pm 0.7 \%$ of all pituitary cells. However, the addition of GHRH did not augment the effect of corticosterone on the proportion of somatotrophs during the final 3 days of incubation.

\section{Responsiveness of corticosterone-induced somatotrophs to GHRH and TRH}

We next assessed whether somatotrophs induced prematurely on e12 by corticosterone treatment were subsequently responsive to GHRH and TRH stimulation. For 


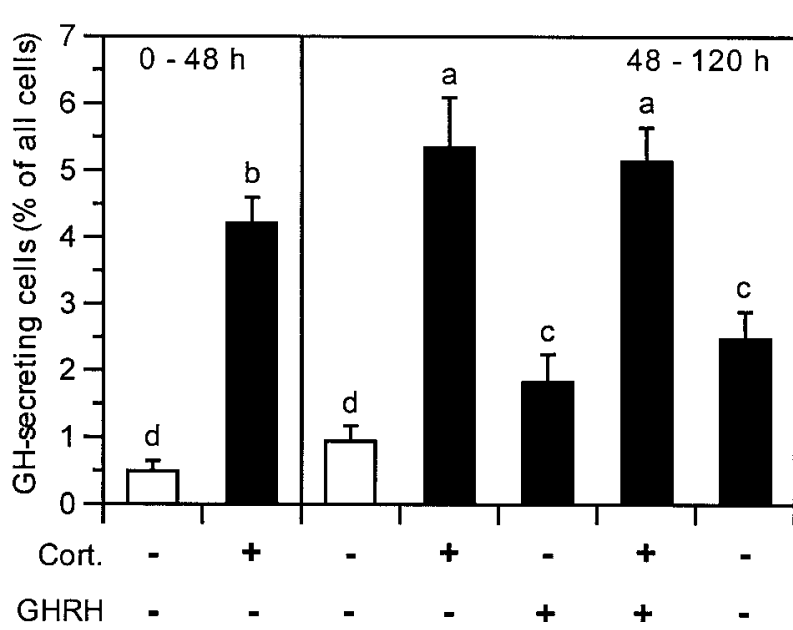

Figure 2 Effect of corticosterone withdrawal on maintenance of induced somatotrophs. E12 pituitary cells were exposed to medium alone or medium containing corticosterone (Cort.; $\left.10^{-9} \mathrm{M}\right)$ for $48 \mathrm{~h}$ in culture. Cells were then recovered, rinsed twice in medium, and cultured for an additional 3 days in medium alone or medium containing corticosterone $\left(10^{-9} \mathrm{M}\right), \mathrm{GHRH}$ $\left(10^{-7} \mathrm{M}\right)$, or corticosterone in combination with GHRH. Cells were then harvested again and subjected to GH RHPA for 8 and $20 \mathrm{~h}$. Results shown are for the 8-h RHPA and are expressed as percentages of total pituitary cells that secreted $\mathrm{GH}$. The presence or absence of corticosterone during the initial $48 \mathrm{~h}$ of culture is denoted by the black bars and white bars respectively. The data are the means \pm S.E. from four independent experiments. Treatments with no letters in common are significantly different from one another $(P<0 \cdot 05)$. Similar results were obtained with plaque assays performed for $20 \mathrm{~h}$ (data not shown).

this purpose, plaque assay chambers incubated for 2 and $4 \mathrm{~h}$ were evaluated, as these incubation intervals were shorter than that required for maximal plaque formation to occur under basal conditions. Cells were first treated with corticosterone for $48 \mathrm{~h}$ and then subjected to the RHPAs with and without secretagogues. The results from this analysis are summarized in Fig. 3. Note that $1 \cdot 5 \pm 0.5 \%$ of all pituitary cells formed GH plaques during the 2-h interval under basal conditions and that GHRH increased this proportion to $4 \cdot 2 \pm 0 \cdot 5 \%$ of all cells $(P<0 \cdot 01 ; n=3)$. During the $4-\mathrm{h}$ interval, $2 \cdot 1 \pm 0 \cdot 5 \%$ of all cells formed GH plaques under basal conditions, and GHRH increased this proportion to $6 \cdot 2 \pm 0 \cdot 5 \%$ of all cells $(P<0 \cdot 01 ; n=3)$. Given that $\mathrm{GHRH}$ increased the percentage of plaque-forming cells by $4 \cdot 1 \%$, we can conclude that at least this proportion of all pituitary cells or about half of all corticosteroneinduced somatotrophs responded to GHRH. Similarly, $4 \cdot 2 \pm 0 \cdot 3 \%$ of corticosterone-treated cells exposed to $\mathrm{TRH}$ for $4 \mathrm{~h}$ released $\mathrm{GH}$ compared with $1.9 \pm 0.3 \%$ of cells exposed to medium alone in the RHPA $(P<0 \cdot 05$; $n=3)$. Comparing this increment in the percentage of plaque-forming cells to the maximal proportion of $\mathrm{GH}-$ releasing cells detected in this experiment $(5 \cdot 0 \%$ of all cells), we can conclude that about half of the somatotrophs present were responsive to TRH.

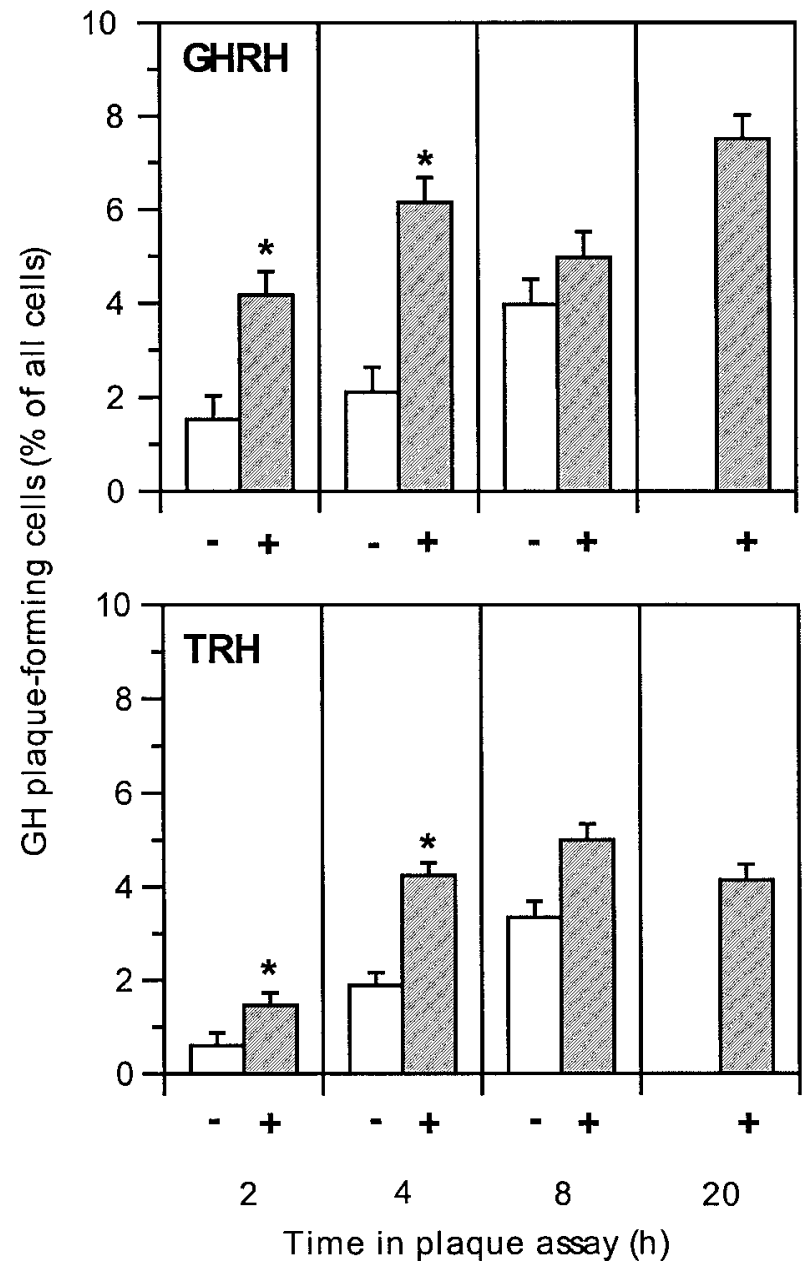

Figure 3 Responsiveness of differentiated $\mathrm{GH}$ cells to GHRH and TRH. E12 pituitary cells were exposed to medium alone or medium containing corticosterone for $48 \mathrm{~h}$ in culture. The cells were then harvested and subjected to RHPAs in the absence or presence of GHRH or TRH. Results are expressed as percentages of total pituitary cells that released $\mathrm{GH}$ following exposure to $10^{-8} \mathrm{M}$ GHRH (top panel) or $10^{-8} \mathrm{M}$ TRH (bottom panel) for 2 to $20 \mathrm{~h}$ in the RHPA. The data are the least squares means \pm S.E. from four experiments for GHRH and three experiments for TRH. Differences between treatment groups within the 2- and 4-h time points, prior to maximal plaque formation under basal conditions, are indicated by asterisks and are significant at $P<0 \cdot 05$.

Localization of corticosterone-responsive somatotroph precursor cells within the pituitary

To determine whether corticosterone initiated GH production by cells distributed evenly throughout the anterior pituitary or whether this response was preferentially restricted to one region, cultures of pituitary cells isolated from the cephalic and caudal halves of the gland were treated for $48 \mathrm{~h}$ with corticosterone $\left(10^{-9} \mathrm{M}\right)$. ICC revealed that corticosterone increased the abundance of $\mathrm{GH}$-containing cells in cultures from the caudal lobe from 


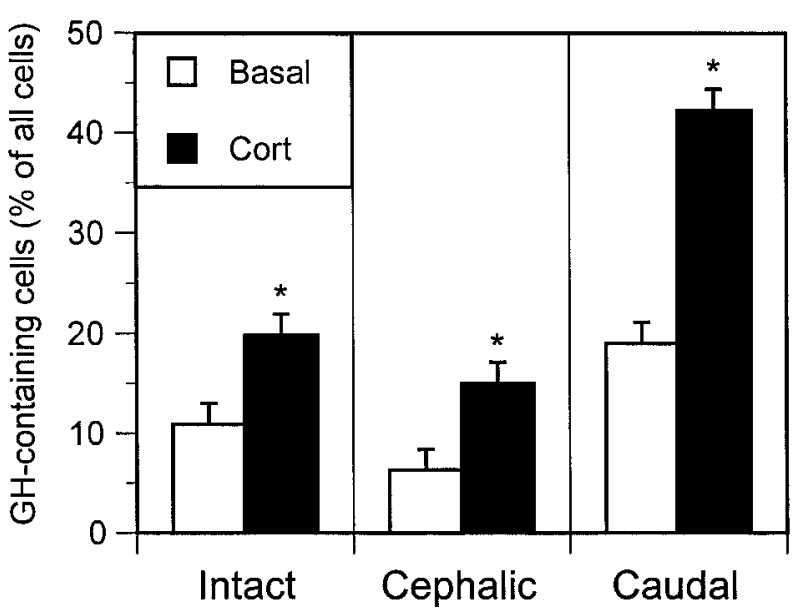

Figure 4 Corticosterone induction of $\mathrm{GH}$-containing cells in cultures derived from the caudal and cephalic lobes of the anterior pituitary. Anterior pituitaries from e12 embryos were cut into their cephalic and caudal halves, with the resulting cephalic and caudal lobes dissociated separately. The resulting cells, along with cells dissociated from entire pituitary glands of other embryos, were treated for $48 \mathrm{~h}$ with corticosterone (Cort; $\left.10^{-9} \mathrm{M}\right)$. GH-containing cells were identified by ICC. The results are presented as the percentage of all cells present that stained positively for $\mathrm{GH}$ and are the least squares means and standard errors from 3 independent trials. Differences between corticosterone and basal treatments are significant at $P<0.01$ and are indicated by asterisks.

the basal proportion of $19 \cdot 0 \pm 2 \cdot 1 \%$ to $42 \cdot 2 \pm 2 \cdot 1 \%$ of all cells (Fig. $4 ; P<0 \cdot 05 ; n=3$ ). In contrast, the abundance of $\mathrm{GH}$ cells in cultures from the cephalic lobe following corticosterone treatment $(15 \cdot 0 \pm 2 \cdot 1 \%)$ was not greater than that found for cultures derived from entire intact glands $(19 \cdot 8 \pm 2 \cdot 1 \%)$. The GH cells induced by corticosterone in the cephalic lobe cell cultures may indicate the presence of somatotroph precursors in both lobes on e12. Alternatively, they may reflect a level of contamination of caudal lobe cells in our cephalic lobe cultures. Given the difficulty inherent in cutting an e12 anterior pituitary in half, we cannot rule out the latter possibility. Nonetheless, the abundance of somatotrophs in corticosterone-treated cultures from the caudal lobe was twice that of similar cultures from the cephalic lobe. These results indicate that glucocorticoid induction of somatotrophs occurs primarily in the caudal lobe of the chicken embryonic anterior pituitary gland, where $\mathrm{GH}$-producing cells normally reside in older embryos and in adults.

\section{Involvement of $\mathrm{GH}$ gene expression in somatotroph differentiation}

RPA and in situ hybridization were used to evaluate GH gene expression in pituitary cell cultures. Total RNA was collected from cells treated with corticosterone for $48 \mathrm{~h}$ and subjected to RPAs to determine total GH mRNA
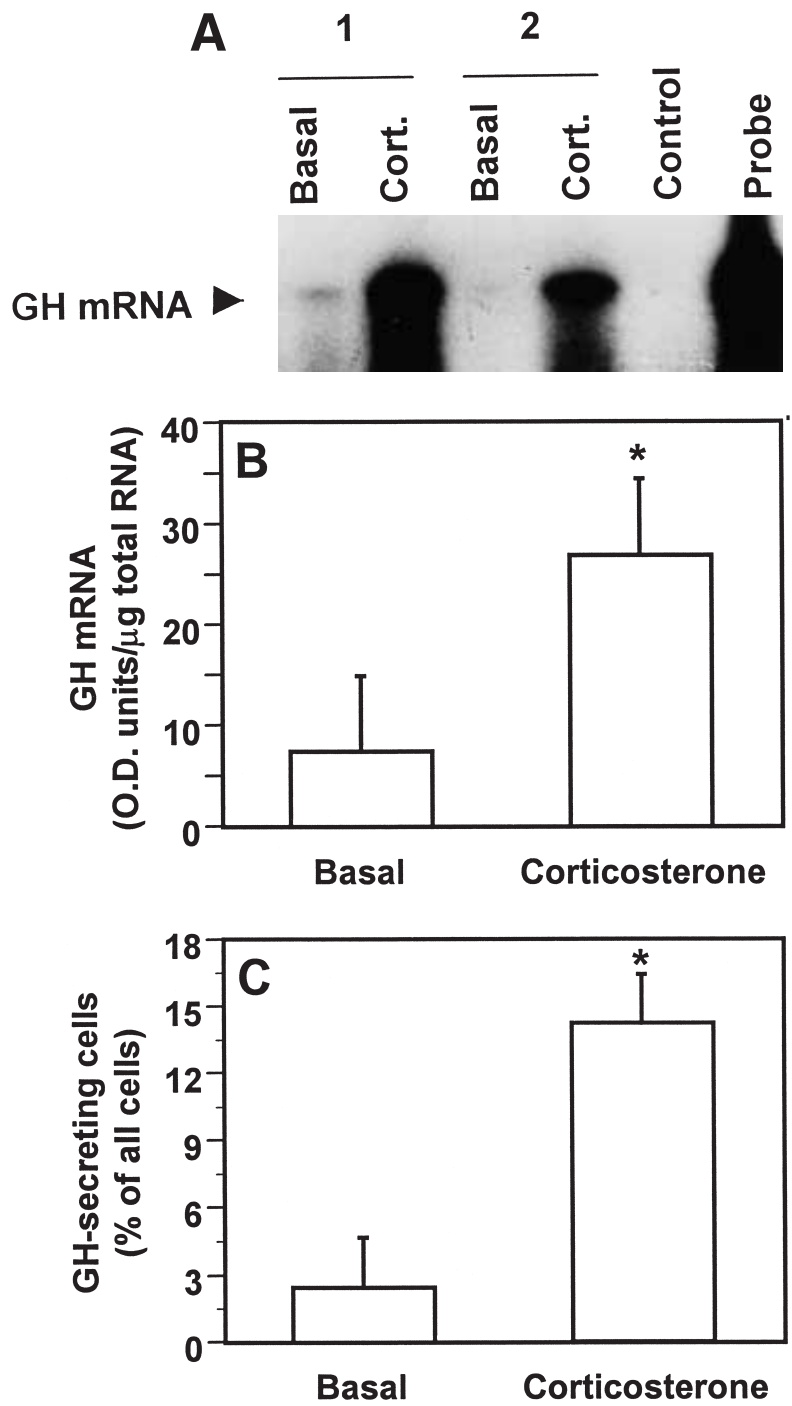

Figure 5 Effect of corticosterone on $\mathrm{GH}$ mRNA levels and $\mathrm{GH}$ cell percentages. E12 pituitary cells $\left(3-5 \times 10^{6}\right.$ cells/treatment) were exposed to medium alone or medium containing corticosterone (Cort.; $10^{-7} \mathrm{M}$ ) for $48 \mathrm{~h}$ in culture. Subsets of these cells were then subjected to GH RHPA (see Fig. 1 for further details), while total RNA was isolated from the remaining cells and analysed for GH mRNA levels by RPA. Results shown are the relative levels of $\mathrm{GH}$ mRNA as determined by RPA (A and B) and the percentages of total pituitary cells that secreted GH (C). Panel A is an autoradiograph showing results of an RPA in which samples from 2 of 4 separate experiments were analysed. Panel B is the densitometric analysis of the autoradiographs from the 4 trials. The data presented in panels $B$ and $C$ are the least squares means \pm S.E. from the 4 separate experiments. The asterisks indicate that treatment with corticosterone significantly increased $(P<0 \cdot 05)$ the percentage of $\mathrm{GH}$-secreting cells and the level of $\mathrm{GH}$ mRNA.

levels in the cultures. Autoradiographic results from 2 of 4 trials are presented in Fig. 5A, and cumulative results from densitometric analysis of 4 independent trials are presented in Fig. 5B. Corticosterone increased the quantity of 


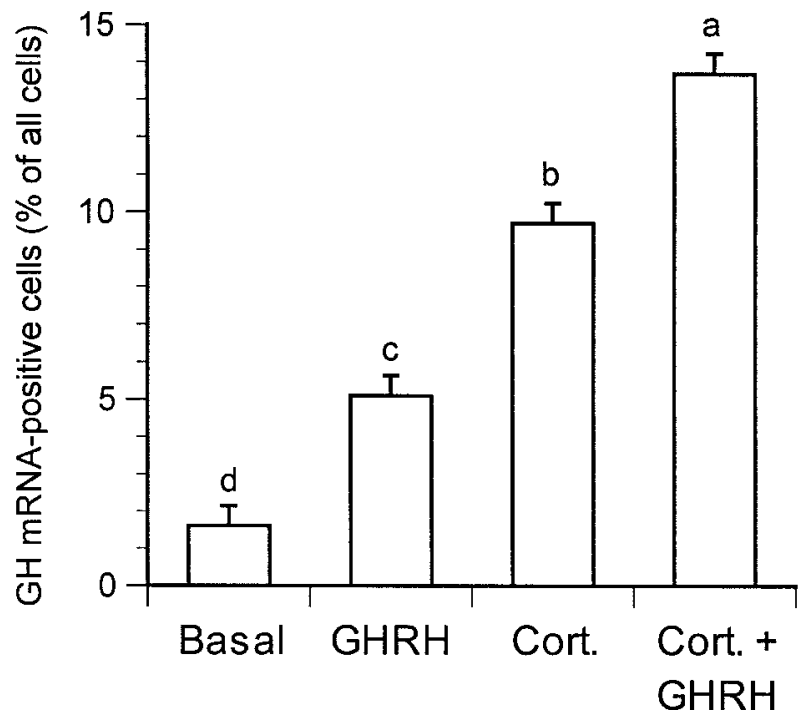

Figure 6 Somatotroph differentiation involves induction of $\mathrm{GH}$ gene expression. E12 pituitary cells were exposed to medium alone or medium containing corticosterone (Cort.; $10^{-9} \mathrm{M}$ ), $\mathrm{GHRH}\left(10^{-7} \mathrm{M}\right)$, or corticosterone in combination with GHRH for 3 days. After culture, the cells were harvested and subjected to in situ hybridization with ${ }^{35}$ S-labelled, antisense riboprobe to chicken $\mathrm{GH}$. The results are the least squares means \pm S.E. from three separate experiments. Significant differences $(P<0 \cdot 01)$ among treatment groups are indicated when bars have no letters in common.

protected GH mRNA from the control level of $7 \cdot 3 \pm 5 \cdot 7$ arbitrary densitometric units (ADU) to $26 \cdot 8 \pm 5 \cdot 7$ ADU per $\mu \mathrm{g}$ total RNA $(P<0 \cdot 05 ; n=4)$. In these same trials, corticosterone increased the proportion of $\mathrm{GH}$ secretors to $14 \cdot 2 \pm 2 \cdot 2 \%$ of all pituitary cells compared with $2 \cdot 4 \pm$ $2 \cdot 2 \%$ of cells cultured in medium alone (Fig. $5 \mathrm{C} ; P<0 \cdot 01$; $n=4)$. To further investigate whether somatotroph differentiation involves induction of $\mathrm{GH}$ gene expression in cells formerly not expressing this gene, e12 pituitary cells were cultured in medium alone or medium containing $10^{-9} \mathrm{M}$ corticosterone, $10^{-7} \mathrm{M}$ GHRH, or corticosterone in combination with GHRH for 3 days. The cells were then subjected to in situ hybridization using a ${ }^{35}$ S-labelled cGH antisense riboprobe. Proportions of pituitary cells expressing $\mathrm{GH}$ mRNA increased from basal levels of $1.6 \pm 0.5 \%$ to $5 \cdot 1 \pm 0.5 \%, 9.7 \pm 0.5 \%$, and $13.7 \pm 0.5 \%$ for cells cultured with GHRH alone, corticosterone alone, and corticosterone in combination with GHRH respectively (Fig. 6). All treatments were significantly different from one another $(P<0 \cdot 01 ; n=3$ separate experiments). Slides hybridized with the sense probe showed no positive cells. Representative photomicrographs from this series of experiments are presented in Fig. 7.

\section{Discussion}

The present series of experiments expands on previous findings and confirms unequivocally that glucocorticoids can induce the differentiation of functional somatotrophs in vitro. Using multiple approaches that assess $\mathrm{GH}$ production at several cellular and molecular levels, we demonstrated that corticosterone increased the level of GH gene expression in cultured cells, and the number of cells that expressed GH mRNA, contained GH protein and released GH into the medium. GH secretion from corticosterone-induced somatotrophs was responsive to GHRH and TRH. These findings indicate that corticosterone initiated $\mathrm{GH}$ gene expression, augmented $\mathrm{GH}$ protein synthesis and induced regulated $\mathrm{GH}$ secretion, the hallmark of a functional somatotroph. In all previous studies with either rat or chicken models, glucocorticoid induction of GH cells was determined either following administration in vivo to the entire animal (Nogami \& Tachibana 1993, Nogami et al. 1995, Dean et al. 1999, Bossis \& Porter 2000) or by using a single approach to define somatotroph differentiation (Hemming et al. 1984, 1988, Morpurgo et al. 1997, Nogami et al. 1997, Dean \& Porter 1999). Where glucocorticoids were administered in vivo, indirect effects from the maternal endocrine system or other tissues in the developing animal could not be excluded, including the potential for stimulation by hypothalamic GHRH. In approaches using a single technique, the possibility remained that only one aspect of $\mathrm{GH}$ production was induced. The current study investigated direct effects of corticosterone on pituitary cells and demonstrated that this glucocorticoid stimulated expression of $\mathrm{GH}$ mRNA and $\mathrm{GH}$ protein and initiated secretion of $\mathrm{GH}$ by a new population of somatotrophs. Considering the body of evidence accumulated to date in rats and chickens, the role of glucocorticoids as extrapituitary factors regulating the final steps in somatotroph differentiation should not be discounted in any model describing GH cell ontogeny.

Corticosterone increased GH mRNA levels in the cultured pituitary cells as detected by RPA, and the increase in GH mRNA in response to corticosterone was due, at least in part, to an increase in the number of cells expressing $\mathrm{GH}$ mRNA. This increase in GH mRNApositive cells and GH mRNA levels could reflect activation of GH transcription and/or stabilization of GH mRNA. The present studies were not designed to distinguish between these possibilities. Glucocorticoids increase pituitary GH mRNA levels in vitro in rats (Nogami et al. 1997) and humans (Paek \& Axel 1987), and these effects are likely mediated, in part, by glucocorticoid response elements (GREs) located in GH genes. The chicken GH gene has been cloned, and its nucleotide sequence including $509 \mathrm{bp}$ of the $5^{\prime}$-flanking region has been determined (Tanaka et al. 1992). A potential GRE is present at -215 to -201 of the chicken GH promoter, and potential GREs were also identified in regions of the human ( -245 to -206$)$ and rat $(-111$ to -97$)$ GH promoters (Robins et al. 1982, Slater et al. 1985, Treacy et al. 1991). However, deletion analysis of genes from rats and humans 


\section{$\mathrm{GH}$ \\ Antisense Riboprobe}
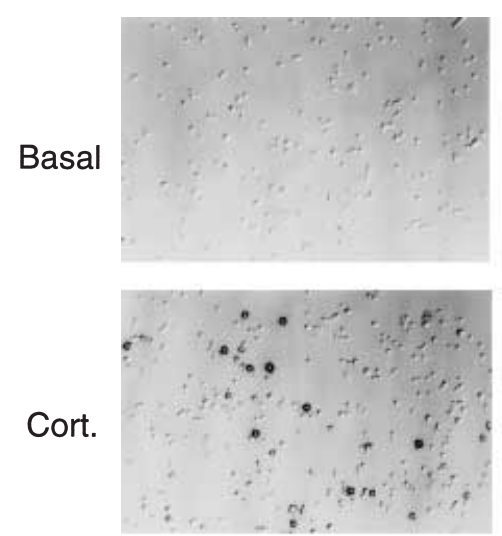

Cort.

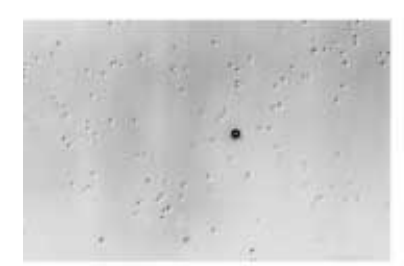

$\mathrm{GHRH}$

Cort. + GHRH

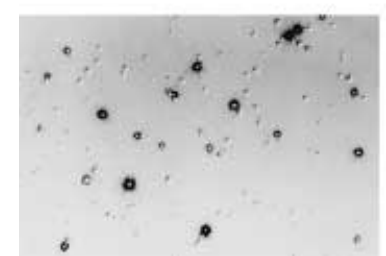

$\mathrm{GH}$

Sense

Riboprobe
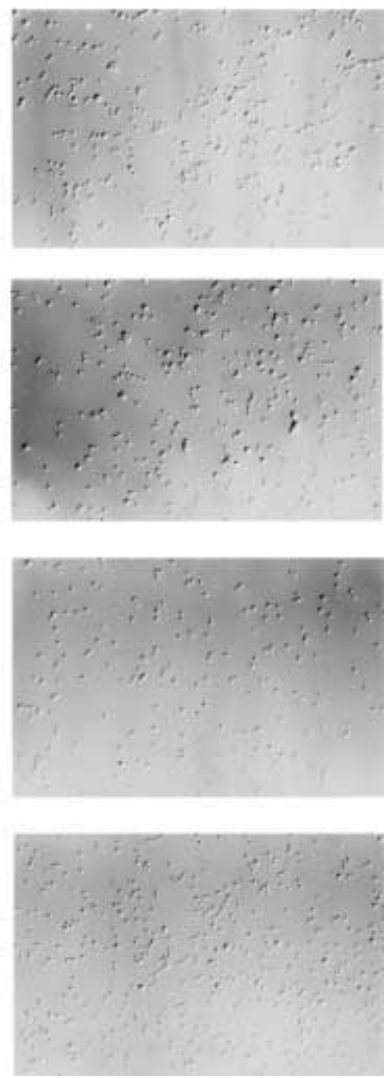

Figure 7 Representative results from in situ hybridization analysis. Cells were treated and analysed as described in the legend to Fig. 6. Shown are the results from a single trial in which e12 pituitary cells were cultured in the presence or absence of corticosterone and GHRH and probed with sense or antisense $\mathrm{GH}$ riboprobes. No positive cells were observed with the sense riboprobe. Note that the abundance of somatotrophs detected with the GH antisense riboprobe was greater in cultures treated with corticosterone alone (Cort.) and in combination with GHRH (Cort.+GHRH).

indicated that sequences mediating glucocorticoid regulation of GH gene expression are primarily located downstream from the transcriptional initiation site (Robins et al. 1982, Slater et al. 1985, Birnbaum \& Baxter 1986, Treacy et al. 1991). A potential GRE is also present within the first intron of the human GH gene (Slater et al. 1985) and in a similar position in the first intron of the chicken $\mathrm{GH}$ gene. The present findings indicate a fairly rapid induction of somatotroph differentiation that is delayed by less than $16 \mathrm{~h}$. This amount of time would be sufficient to induce GH gene expression, protein synthesis, hormone packaging and release. Induction of each of these events is indicated by our present results. The length of time required for corticosterone to augment $\mathrm{GH}$ cell abundance would also be sufficient for the production of intermediate factors that could, in turn, induce GH cell differentiation. Protein synthesis is required for premature induction of GH mRNA in cultured fetal rat pituitary cells (Nogami et al. 1997), supporting the involvement of an intermediary protein. Unpublished results in our laboratory have confirmed this in cultured pituitary cells from embryonic chickens. Thus, the induction of GH mRNA by glucocorticoids that is associated with somatotroph differentiation might not be a direct effect of glucocorticoids on the GH gene, but an effect mediated by a factor produced in the pituitary in response to glucocorticoids. The nature of this protein and whether it is produced within the presomatotrophs or another cell type is not known. 
Pituitary GH release in chickens, as in other vertebrates, is controlled by stimulatory and inhibitory factors from the hypothalamus. GHRH and TRH are thought to be the primary stimulatory GH secretagogues in chickens. In previous studies, 50 to $70 \%$ of initial somatotrophs present on e16 released GH in response to GHRH (Porter et al. 1995a, Dean et al. 1997), while only 30\% of e16 GH cells were responsive to TRH (Dean et al. 1997). By e20, proportions of somatotrophs that responded to GHRH and TRH were approximately equal. Following treatment of e12 pituitary cells with corticosterone in the present study, at least $50 \%$ of somatotrophs present were responsive to GHRH and TRH. Thus, somatotrophs induced prematurely by treatment with corticosterone on e12 are at least as responsive to GHRH and TRH as GH cells that differentiate normally by e16. In addition, corticosterone induction of somatotrophs occurred primarily in cultures from the caudal lobe of the anterior pituitary. While many $\mathrm{GH}$-containing cells were induced in cultures derived from the cephalic lobe, nearly half of all cells obtained from the caudal lobe produced GH in response to corticosterone. The caudal lobe of the anterior pituitary is the same region where somatotrophs are located in adults (Lopez et al. 1995) and where GH mRNA is expressed prematurely in response to corticosterone administration in vivo (Bossis $\&$ Porter 2000). Together, these findings indicate that the corticosterone-induced population of GH cells likely reflects those cells that were destined to differentiate into somatotrophs at a later age and that the induced somatotrophs are fully functional in their responses to GHRH and TRH. It follows that the induced GH cells were already committed to the somatotroph lineage, and that corticosterone functions as the final signal to induce the mature somatotroph phenotype.

Previous work by our group established that, in contrast to corticosterone, treatment of e 12 chicken pituitary cells with GHRH for as many as 6 days failed to increase the percentage of GH-secreting cells (Porter et al. 1995b, Dean \& Porter 1999). This finding was surprising, because GHRH has been shown to stimulate proliferation of rat somatotrophs in vitro (Billestrup et al. 1986). However, treatment of e12 chicken pituitary cells with corticosterone in combination with GHRH resulted in a greater stimulation in the proportion of somatotrophs than treatment with corticosterone alone (Dean \& Porter 1999). In the present study, combined treatment with GHRH and corticosterone resulted in more GH mRNA-positive cells than treatment with corticosterone alone. Treatment of e12 chicken pituitary cells with GHRH alone for 3 days increased the percentage of $\mathrm{GH}$ mRNA-positive cells 3.2-fold over basal levels, while treatment with corticosterone alone was nearly twice as effective, increasing the percentage of positive cells to $6 \cdot 1$ times that of controls. Corticosterone and GHRH exerted an additive effect, as treatment with both hormones increased the proportion of GH mRNA-positive cells to $13 \cdot 7 \%$ of all pituitary cells, an 8.6-fold increase over the control level. These results, together with previous findings, indicate that GHRH is effective at increasing GH mRNA expression in existing somatotrophs and may act in conjunction with glucocorticoids to induce $\mathrm{GH}$ gene expression during somatotroph differentiation. However, we also found that withdrawal of corticosterone for 3 days diminished the abundance of somatotrophs, although not to proportions as low as those found in cultures never treated with corticosterone. Exposure to GHRH during the corticosterone withdrawal period failed to maintain the increased proportion of somatotrophs induced by corticosterone. Thus, corticosterone-induced increases in the proportion of somatotrophs are at least partially reversible and apparently dependent upon the continuous presence of corticosterone. This finding would indicate that glucocorticoids act as both a differentiating factor and as a trophic factor for somatotrophs during embryonic development that cannot be substituted for by GHRH.

Our present findings support the hypothesis that glucocorticoids induce somatotroph differentiation. Analysis by in situ hybridization, immunocytochemistry and reverse haemolytic plaque assays indicated a corticosteroneinduced increase in the abundance of GH cells. An alternative interpretation of these findings is that the trophic actions of corticosterone merely increased $\mathrm{GH}$ gene expression, protein production and hormone release by a population of existing somatotrophs above the levels of sensitivity for each of these assays. However, it seems unlikely that each of these sensitive techniques was unable to detect this population of somatotrophs. Furthermore, in our previous reports (Porter et al. 1995b, Morpurgo et al. 1997, Dean \& Porter 1999) treatment with GHRH or $\mathrm{TRH}$, the principal stimulatory $\mathrm{GH}$ secretagogues in chickens, for 2 to 6 days failed to increase the abundance of GH-secreting cells in cultures of embryonic pituitary cells. Similarly, the aqueous phase of ether-extracted embryonic serum failed to induce GH cell differentiation (Morpurgo et al. 1997). In contrast, the ether phase effectively induced GH-secreting cells, and the somatotroph-differentiating activity in the embryonic serum was found to be corticosterone. Currently, we found that somatotroph induction in response to corticosterone is rapid, occurring within $16 \mathrm{~h}$. Thus, glucocorticoids would appear to be more than a mere trophic regulator of $\mathrm{GH}$ expression. Rather, they seem to be a requisite factor for final expression of the somatotroph phenotype, a role that cannot be substituted for by either GHRH or TRH. However, our current findings do indicate that somatotrophs induced by corticosterone are responsive to both TRH and GHRH. Either TRH and GHRH receptors were already present on these cells prior to corticosterone induction of $\mathrm{GH}$, or corticosterone induced their expression in addition to GH. Whether glucocorticoids act to change the fate of a progenitor population into the somatotroph lineage or, instead, act as 
a final signal regulating the differentiation of functional somatotrophs from cells already committed to this lineage is difficult to address. Our findings that the corticosterone response occurs within $16 \mathrm{~h}$, that these cells arise predominantly in their normal microanatomical location, and that they respond as normal somatotrophs to TRH and GHRH tend to favour the latter possibility. We conclude that glucocorticoids may function as a requisite signal for induction of the final stages of somatotroph differentiation from cells that are already committed to this lineage.

\section{Acknowledgements}

This work was supported by USDA Grants 97-352065086 (to TE P) and 96-35206-3493 (to CE D) and by the Maryland and Texas Agricultural Experiment Stations.

\section{References}

Barabanov VM 1991 Determination of adenohypophysis cytodifferentiation during embryonic development. Ontogenez 22 175-181

Billestrup N, Swanson LW \& Vale W 1986 Growth hormonereleasing factor stimulates proliferation of somatotrophs in vitro. PNAS 83 6854-6857.

Birnbaum MJ \& Baxter JD 1986 Glucocorticoids regulate the expression of a rat growth hormone gene lacking $5^{\prime}$ flanking sequences. Journal of Biological Chemistry 261 291-297.

Bossis I \& Porter TE 2000 Ontogeny of corticosterone-inducible growth hormone-secreting cells during chick embryonic development. Endocrinology 141 2683-2690.

Castrillo J, Theill LE \& Karin M 1991 Function of the homeodomain protein GHF1 in pituitary cell proliferation. Science $\mathbf{2 5 3}$ 197-199.

Chomczynski P \& Sacchi N 1987 Single-step method of RNA isolation by acid guanidinium thiocyanate-phenol-chloroform extraction. Analytical Biochemistry 162 156-159.

Dean CE \& Porter TE 1999 Regulation of somatotroph differentiation and growth hormone $(\mathrm{GH})$ secretion by corticosterone and $\mathrm{GH}-$ releasing hormone during embryonic development. Endocrinology 140 1104-1110.

Dean CE, Piper M \& Porter TE 1997 Differential repsonsiveness of somatotrophs to growth hormone-releasing hormone and thyrotropin-releasing hormone during chicken embryonic development. Molecular and Cellular Endocrinology 132 33-41.

Dean CE, Morpurgo B \& Porter TE 1999 Induction of somatotroph differentiation in vivo by corticosterone administration during ckicken embryonic development. Endocrine 11 151-156.

Frawley LS, Hoeffler JP \& Boockfor FR 1985 Functional maturation of somatotropes in fetal rat pituitaries: analysis by reverse hemolytic plaque assay. Endocrinology 116 2355-2360.

Hemming FJ, Begeot M, Dubois MP \& Dubois PM 1984 Fetal rat somatotropes in vitro: effects of insulin, cortisol, and growth hormone-releasing factor on their differentiation. A light and electron microscopic study. Endocrinology 114 2107-2113.

Hemming FJ, Aubert ML \& Dubois PM 1988 Differentiation of fetal rat somatotropes in vitro: effects of cortisol, 3, 5, 3'-triiodothyronine, and glucagon. A light microscopic and radioimmunological study. Endocrinology 123 1230-1237.

Ingraham HA, Chen R, Mangalam HJ, Elsholtz HP, Flynn SE, Lin CR, Simmons DM, Swanson L \& Rosenfeld MG 1988 A tissuespecific transcription factor containing a homeodomain specifies a pituitary phenotype. Cell 55 519-529.

Jozsa R, Scanes CG, Vigh S \& Mess B 1979 Functional differentiation of the embryonic chicken pituitary gland studied by immunohistological approach. General and Comparative Endocrinology 39 158-163.

Lamb IC, Galehouse DM \& Foster DN 1988 Chicken growth hormone cDNA sequence. Nucleic Acids Research 169339.

Li S, Crenshaw EB, Rawson EJ, Simmons DM, Swanson LW \& Rosenfeld MG 1990 Dwarf locus mutants lacking three pituitary cell types result from mutations in the POU-domain gene Pit-1. Nature 347 528-533.

Lin C, Lin SC, Chang CP \& Rosenfeld MG 1992 Pit-1-dependent expression of the receptor for growth hormone-releasing factor mediates pituitary cell growth. Nature 360 765-768.

Lopez ME, Hargis BM, Dean CE \& Porter TE 1995 Uneven regional distributions of prolactin- and growth hormone-secreting cells and sexually dimorphic proportions of prolactin secretors in the adenohypophysis of adult chickens. General and Comparative Endocrinology 100 246-254.

Morpurgo B, Dean CE \& Porter TE 1997 Identification of the bloodborne somatotroph-differentiating factor during chicken embryonic development. Endocrinology 138 4530-4535.

Neill JD \& Frawley LS 1983 Detection of hormone release from individual cells in mixed populations using a reverse hemolytic plaque assay. Endocrinology 112 1135-1137.

Nemeskeri A, Setalo G \& Halasz B 1988 Ontogenesis of the three parts of the fetal rat adenohypophysis. Neuroendocrinology 48 534-543.

Nogami H \& Tachibana T 1993 Dexamethasone induces advanced growth hormone expression in the fetal rat pituitary gland in vitro. Endocrinology 132 517-523.

Nogami H, Suzuki H, Enomoto H \& Ishikawa H 1989 Studies on the development of growth hormone and prolactin cells in the rat pituitary gland by in situ hybridization. Cell and Tissue Research 255 23-28.

Nogami H, Yokose T \& Tachibana T 1995 Regulation of growth hormone expression in fetal rat pituitary gland by thyroid or glucocorticoid hormone. American Journal of Physiology 268 E262-E267.

Nogami H, Inoue K \& Kawamura K 1997 Involvement of glucocorticoid-induced factor(s) in the stimulation of growth hormone expression in the fetal rat pituitary gland in vitro. Endocrinology 138 1810-1815.

Paek I \& Axel R 1987 Glucocorticoids enhance stability of human growth hormone mRNA. Molecular and Cellular Biology 7 1496-1507.

Porter TE, Couger GS, Dean CE \& Hargis BM 1995a Ontogeny of growth hormone $(\mathrm{GH})$-secreting cells during chicken embryonic development: initial somatotrophs are responsive to $\mathrm{GH}$-releasing hormone. Endocrinology 136 1850-1856.

Porter TE, Couger GS \& Morpurgo B $1995 b$ Evidence that somatotroph differentiation during chicken embryonic development is stimulated by a blood-borne signal. Endocrinology 136 3721-3728.

Rieutort M 1974 Pituitary content and plasma levels of growth hormone in foetal and weanling rats. Journal of Endocrinology 60 261-268.

Robins DM, Paek I, Seeburg PH \& Axel R 1982 Regulated expression of human growth hormone genes in mouse cells. Cell 29 623-631.

Rodriguez-Garcia M, Jolin T, Santos A \& Pirez-Castillo A 1995 Effect of perinatal hypothyroidism on the developmental regulation of rat pituitary growth hormone and thyrotropin genes. Endocrinology 136 4339-4350.

Slater EP, Rabenau O, Karin M, Baxter JD \& Beato M 1985 Glucocorticoid receptor binding and activation of a heterologous 
promoter by dexamethasone by the first intron of the human growth hormone gene. Molecular and Cellular Biology 5 2984-2992.

Smith PF, Luque EH \& Neill JD 1986 Detection and measurement of secretion from individual neuroendocrine cells using a reverse hemolytic plaque assay. Methods in Enzymology 124 443-465.

Tanaka M, Hosokawa Y, Watahiki M \& Nakashima K 1992 Structure of the chicken growth hormone-encoding gene and its promoter region. Gene 112 235-239.
Treacy MN, Ryan F \& Martin F 1991 Functional glucocorticoid inducible enhancer activity in the $5^{\prime}$-flanking sequences of the rat growth hormone gene. Journal of Steroid Biochemistry and Molecular Biology 38 1-15.

Received 2 February 2001

Accepted 15 February 2001 